\title{
Assisting the government in the implementation Non-formal education: a case study of the Indonesian Kasih Bundo Institute for the care and development among the disables children
}

\author{
Eka Pasca Surya Bayu ${ }^{*} 1$, Mira Meilisa ${ }^{2}$ \\ ${ }^{12}$ Universitas Muhammadiyah Sumatera Barat \\ *) Corresponding author, $\equiv$ e-mail: ekapascha.suryabayu@gmail.com
}

\begin{abstract}
Poverty is still a serious issue worldwide, including in Indonesia. One important way to address it is by providing education by the government. However, the government alone cannot address the problem satisfactorily and, therefore, it needs non-governmental organisations (NGOs) to assist. One of these types of NGOs is Yayasan Penyantun dan Pembina Anak Cacat (YPPAC) Kasih Bundo. This NGO assists the government by providing a non-formal education by establishing Pusat Kegiatan Belajar Masyarakat (PKBM) Kasih Bundo (The Kasih Bundo Study Centre for the Community). This article reports a study on this NGO, focusing on what it has done and what it has successfully achieved by looking at the social and economic background of their families. The result suggests that the NGO has successfully assisted the government in a significant manner.
\end{abstract}

Keywords: non-formal education, disable children

How to Cite: Bayu, E. P. S., Meilisa, M. (2017). Assisting the government in the implementation Non-formal education: a case study of the Indonesian Kasih Bundo Institute for the care and development among the disables children. Couns-Edu: International Journal of Counseling and Education, 2(3): pp. 112-118. DOI: https://doi.org/10.23916/002017026930

(i) This is an open access article distributed under the Creative Commons Attribution License, which permits unrestricted use, distribution, and reproduction in any medium, provided the original work is properly cited. (C2017. Indonesian Counselor Association (IKI).

\section{Introduction}

The Indonesian 'Kasih Bundo' Institute For The Care And Development of Disable Children (YPPAC) was established in 1988 with the main task to assist and support the implementation of the Indonesian government policy regarding disable children, including in providing accommodation (boarding), care and education for disabled children, abandoned children, children from poor families and children from remote areas, in particular, to provide compulsory education. A major issue faced by this NGO since 2001 is the fact that all the inmates are dropouts from formal (non-special) schools. Social conditions of inmate's low educational background did not even finish primary school influence in realizing the objectives of social services humanitarian foundation in terms of the welfare of Citizens Social Patronage. With low levels of education, the future access to jobs that could be pursued guided the citizens will be low, as a result of their income in later to be low as well. Thus increasing the degree of social and social welfare will be difficult social inmates sought.

Referring to these conditions, the implementation of the activities of the foundation needs to be developed to support the policy program of School Education Department of Education Bukittinggi in Village of Manggis Ganting be coordinating and providing the Program Package A, Package B and Package $\mathrm{C}$ are considered appropriate and conducive to Citizens Patronage Social Foundations. Making 
education as one integrative solutions in the implementation of social welfare in order to break the chain of poverty.the Foundation must play an active role in managing and developing the Non-Formal Education through especially equal education access services that exist in an integrative way, planned and sustainable.

Social welfare problems that grow and thrive due to the absence of most citizens of Indonesia unmet basic rights / basic needs adequately due to unserved by the state. Neglected and non-fulfillment of the rights of citizens in the field of education is a field of social development should be done with the community, family, and government. Meeting the needs of education services for children who have problems (who dropped out of school) is an early prevention occurrence of many new social problems (Purwanto, E. A., 2007; Mumford, M. D., Zaccaro, S. J., Harding, F. D., Jacobs, T. O., \& Fleishman, E. A., 2000; Wilkinson, R., \& Pickett, K., 2010; Best, J., 2003) for children and the community.

In accordance with Act No. 20 of 2003 Article 26, paragraph 1 of the National Education System state that the Non-Formal Education organized for citizens who require educational services that act as substitutes, adders, and or complementary non-formal education in order to support lifelong education. Non-Formal Education (NFE) (Gee, K. A., 2015; Yasunaga, M., 2014; Kaufmann, K., 2015; Nieto, S., \& Ramos, R., 2013; Olcott, D., 2013; Souto-Otero, M., Ulicna, D., Schaepkens, L., \& Bognar, V., 2013; Preece, J., 2013; Stromquist, N. P., 2015) can be seen as an educational approach which may act in a complementary way with the formal educational system. We need a Community Learning Center (CLC) known PKBM as an educational unit that will hold non-formal education according to the needs of society assuming the initiative of, by, and for the public as the Government Regulation No. 17 of 2010 Article 1, paragraph 33. Therefore, since the academic year, 2004/2005 YPPAC Bukittinggi via Institution of Social Services "Kasih Bundo" develop alternative education as non-formal education units, to meet the needs of school dropouts and children who experience other problems in Bukittinggi.

Environmental conditions PKBM Kasih Bundo is one brick-producing areas in Bukittinggi. Work are for the people of lower economic. Though the condition is now developing housing sites, colleges, shops that will help change the economic community, but there are still plenty of people around who are having problems in the economic field, causing the child from the family dropped out of school.

Based on data from the last 3 years is known to occur an increase in the number of learners who access non-formal education in the education program equality Package A, Package B and Package C with various backgrounds causes of dropouts. The number of people learning each year has increased. One thing of concern is the age of the learners who access education mostly school-age children who naturally must obtain formal education.

Based on the above, researchers interested in conducting a case study on the role of community institutions in organizing non-formal education. The purpose of this study is to analyze how the role of non-formal education in an effort to break the chains of poverty by knowing the background of children who have dropped out of school and their family's economic background.

\section{Method}

According to the purpose of research which has been described previously, then this type of research is descriptive qualitative research. Qualitative descriptive study is meant here is to view, review, and a portrait of the object under study as it is without controlling towards a treatment and finally draws a conclusion about it. The data obtained from the field will be described through words by researchers. Can also be said that a qualitative descriptive study was intended to elevate the facts, circumstances, variables and phenomena that occur (when the research is ongoing) and presents what it is. Thus, in this study do not need to test hypotheses and make predictions result. 


\section{COUNS-EDU}

Vol.2, No.3, Month 2017

Available online: http://journal.konselor.or.id/index.php/counsedu

E.P.S.Bayu \& Mira Meilisa

In collecting the data in this study used triangulation method Arikunto, S. (2002). The data collection instruments used in this study are:

1. Observation

Observations conducted to determine the various activities undertaken in the implementation of nonformal education for the last five years. Observations carried out continuously during the four months of data collection.

\section{Technical Documentation}

Technical documentation was conducted to determine information about the background of the learners and their families so that the economy dropped out of school. Additionally, it will examine all measures taken in achieving the objectives of PKBM Kasih Bundo.

\section{Interview}

The interview is data collection through the oral debriefing process that goes in one direction, meaning that the question came from parties who interviewed and the answers given by the interviewee. In this study interviewed was three resource persons who have set up and manage PKBM Kasih Bundo. From a standing start from the present. Interviews were also intended to determine further details on the results of observation and analysis of documentation done.

The results obtained will be reported well in order to be known by others. The results obtained should be analyzed by qualitative data analysis. According to the model of Miles and Huberman (in Sugiyono, 2005), qualitative data analysis is' activity in qualitative data analysis performed interactively and runs continuously until complete, so that the data is already saturated ". Based on this, the inner workings of data analysis techniques starting from data reduction, data presentation, and then verified. This activity is performed at the time of the study. Furthermore, if there is a lack of data or there is an error that the data obtained are less in accordance with what is expected, then do the process again with the same stage. The steps in the data analysis are as follows:

Data reduction

1. Reduction of data in this research is done in the form of the electoral process, focusing of attention, selection, editing and simplification obtained from field notes.

2. Presentation of data in this research is done in the form of narrative text based on the observation, video taping, and interviews, which were reduced during the study.

3. Verification of data, verification or drawing conclusions in this paper are to review or validate the data that has been obtained previously. Drawing conclusions drawn based on theories regarding content standards, standardized processes, and assessment standards.

\section{Results and Discussions}

Integrating social foundations of education as a development pattern in addressing issues that focus poverty requires thinking and continuous innovation. Social Homes not in the beginning it is needed in the handling of social problems. However, according to the development of science to do various kinds of new methods in handling social problems. Social institutions that provide services to specialist educational options on a special line that is at a special school (SLB). This is the primary education is helpful, but not all types of specificity should always be at the school. Nationally also developed their inclusive education, to enable children in special need's education in addition to SLB. Further life after school time can be passed well, of course, with the skills and knowledge more.

Development of the role of social institutions not only providing accommodation for children with disabilities to be able to stay in a rehabilitation center, but also displaced. Therefore, the diverse backgrounds of children in social institutions need to be handled more especially for their education. In addition, the environmental conditions of the social institutions that have low economic cause's parlors open access shelter for children from local residents. With that in mind, of course, is also needed container for education that can be accessed to improve the quality of self. Therefore, an attempt to make gradual in the end is educational equality that originally cooperated with the village. However, due to the distance 
from home is quite far away, causing poor results as well. Came the initiative to provide access to education itself under YPPAC called PKBM Kasih Bundo.

All efforts were made based on experience and observation of the needs within the community. For that we need a pattern developed to improve the welfare of society. It was stated in a pattern diagram empowerment as a potential source of social welfare development strategy PKBM independence in the management of Kasih Bundo YPPAC Bukittinggi runs until now. This diagram is also likely to be a pattern of breaking the cycle of poverty be pursued can be implemented optimally.

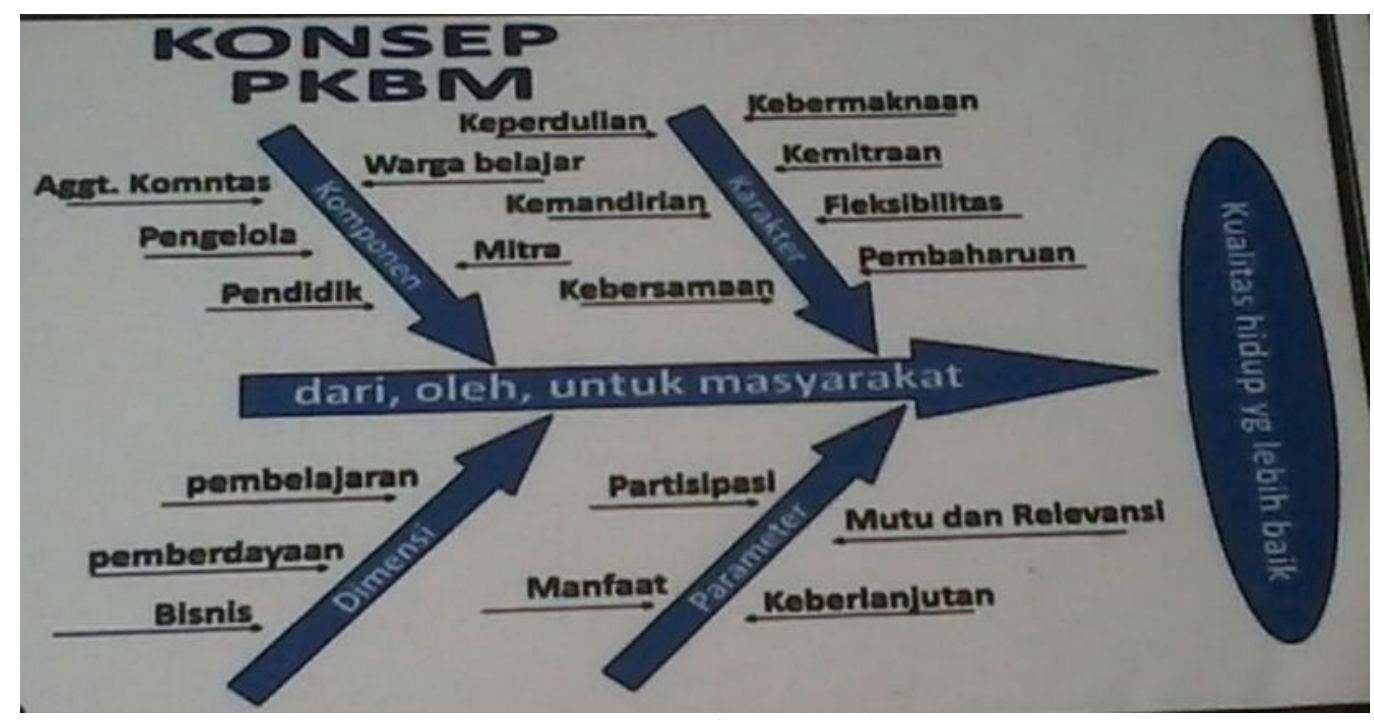

Diagram 1. Concept of CLC Kasih Bundo

To break the chain of poverty in the chart is known, one way is to improve public education. Implementation of the Education Equality is one alternative education that can be followed to obtain the right to education. Notch education and graduates equated with formal education equivalent. Based on data obtained known that from the beginning of the number of learners has increased. Residents learn not only from the city of Bukittinggi, but also from the area around Bukittinggi. below:

Based on the data collected, the number of people studying the past five years can be seen in Table 1

Table 1. The Number of people studying the past five years

\begin{tabular}{lllllll}
\hline Program & $\mathbf{2 0 1 2 / 2 0 1 3}$ & $\mathbf{2 0 1 3 / 2 0 1 4}$ & $\mathbf{2 0 1 4 / 2 0 1 5}$ & $\mathbf{2 0 1 5 / 2 0 1 6}$ & $\mathbf{2 0 1 6 / 2 0 1 7}$ & Total \\
\hline Package A & 35 & 60 & 70 & 64 & 111 & 340 \\
Package B & 116 & 143 & 129 & 115 & 117 & 620 \\
Package C & 114 & 92 & 116 & 101 & 99 & 522 \\
Total & 265 & 295 & 315 & 280 & 327 & 1.482 \\
\hline
\end{tabular}

Based on the above table it is known that the number of people learning a whole can be said to increase. This should be a concern for all of us, because of the large number of school dropouts who are at the age of compulsory and should have access to education equality. This is due to several factors, among others, the discipline in which people learn to fail to comply to the rules on formal schooling, a policy area in which to be able to access the education required proof of residency and population data, so that the learners who find it difficult in urban administration. In addition, education in the city of Bukittinggi not only accommodates students from Singapore, but also from outside London, so the capacity of the school to accommodate school-age citizens is also reduced. Bukittinggi town that has a good-quality education, indirectly attract the attention of people who live outside the city of Bukittinggi. 


\section{COUNS-EDU •}

Vol.2, No.3, Month 2017

Formerly, educational equality education be a substitute, but now it can be said that equality of education could be an alternative education that is accessible if it cannot proceed to formal education. Although the guidelines are there still no reference to the age of the learners who can join the program equality. Besides getting out of the economic problems, there are still about $20 \%$ of those studied who dropped out of school because of this factor. Not just because their parents are less capable, but also the custom in the area that teaches children an early age to earn so forget the importance of education. At the time no longer sufficient income, educational needs began to be felt, and finally follow the equivalency education program.

Implementation of educational equality in PKBM Kasih Bundo consists of several programs. A program package consists of one level is the ground level where they are composed of grade 4, 5 and six primary school. In the reference, the voter's equal learning is a group. However, in PKBM Kasih Bundo, they split into two classes to optimize learning and prepare citizens to learn the final level to be more focused on national exams (UN). The program package is composed of two groups: one skilled similar class VII and VIII and IX equivalent grade Skilled 2. Whereas C according to the rule's package is of two similar groups: Advanced 1 and Advanced 2 has class X, XI and XII grade equivalents. Mahir 2 in PKBM KasihBundo is majoring in social studies. Implementation of learning in the package $C$ is somewhat different from the package $\mathrm{A}$ and package $\mathrm{B}$. The group that should have been in the application are merged into one class. Although residents remain differentiated for group learning. C-face somewhat less than other programs. Residents learn $C$ packets that have passed school age prosecute them should seek their own money and in addition to families. It is difficult for a maximum attendance. Nevertheless, they remain saddled with the task independently in the reference Credit Competency Standards (SKK).

Facing a variety of backgrounds, residents learned that there needed tutors as teachers are strong mentally, because of school children in most cases have a habit that is freer than his age. The difficulties encountered are in terms of discipline, courtesy, and lifestyle habits that are less control of the family against their religion. For that all tutors are responsible to grow the character of students in various ways that feel right for each field of science.

As PKBM piloting to character education, perceived difficulties in the development and formation of the character itself. Modeling is becoming one of the powerful weapons were sometimes unable to successfully maximize. This is because the characteristics of the Education Equality learning itself that residents cannot be forced to always be present and follow formal learning such as schools. Residents learn that change from individual each year is also a cause of trouble. Residents learn new ones following study at CLC will require more attention to be formed character corresponding existing programs. In recent years, the focus of CLC in shaping the character of the learners focused on religious, honest, responsibility, tolerance, and 5S (smiles, greetings, greetings, polite and courteous).

Changes made to the participants in the knowledge, and character cannot be done only in the CLC only. However, support should also be provided by parents at home. The CLC provides books for liaison between teachers and parents to control the activities of citizens to learn every day. However, the liaison book does not get a response that is too good. Many parents who do not pay attention to the teacher's notes in the book, so that communication cannot be established properly. It also conducted regular meetings with parents or guardians of learners to provide information on the progress of their child for at PKBM Kasih Bundo.

Non-formal Education (NFE) consists in a gathering of educational practices which are not included in the formal system of education (Romi, S., \& Schmida, M., 2009; Kuenzi, M., 2005; Thompson, E. J., 2001; Kedrayate, A., 2012; Mfum-Mensah, O., 2003; Morton, M. H., \& Montgomery, P., 2012). Given knowledge cannot only through the material without practice. However, not all subjects could practice the activities designed by the tutors because of the limitations of existing facilities. However, the practice is focused in the field of worship. Because based on the results of data collection conducted by tutors in PKBM in their respective classes in general the study. This is because there is the family of the learners who did not introduce and exemplify it. So that other activities such as the practice of prayer, prayer congregation, reading the verses of the Qur'an and deposited verse also charged to the learners. 
According to the rules required the implementation of Education Equality debriefing in the field of skills. For that, residents learn according to their interests given the freedom to choose the desired skills program. The skills that are taught in the form of patchwork fabric processing into items that can be sold as a brooch veil, a former magazine paper is used as bracelets and necklaces, as well as culinary skills. It is given so that learners can improve creativity, able to conduct entrepreneurial activities. Handicraft goods marketed either in a specific exhibition and the visitors who come to PKBM Kasih Bundo. Whereas the cookery activities are already people learning to make food and sale at the canteen in PKBM Kasih Bundo. In addition, learners also given the opportunity to show your creations outside of the skills taught in the CLC and asked to share with colleagues to foster self-confidence and the spirit of a more optimal work again in the future.

Achieving the goal of the integration is done PKBM seen output of alumni who was there several years. Based on the information that is not all the learners who participate in education equality leads to job seekers. However, most of them continue their education at a higher level. Indirectly development of logic by the tutor and also structural PKBM broadens citizens to learn to be a person with new thinking. With increased education or less will bring changes to the family economy. Because eligible for employment seen from the quality of education that has been resolved. Not only that, CLC has also helped government officials that need assistance for the improvement of education, because the requirement to become an employee is to have at least high school education. So that government employees continue their education through the program Package $\mathrm{C}$ with permission from the relevant authorities.

Based on the above, it can be seen that the required educational alternative educational path that is consistent in its implementation. Each city or county must have at least one education provider equality every district so that learners gain the ease of access to education when experiencing difficulties in the formal channels. However, keep in mind that a good management to the management in order to achieve the fullest. It can be said that the PKBM KasihBundo has been able to perform tasks as a container that equal education in the city of Bukittinggi, but it must be anticipated also that non-formal education to remain high as the first major educational paths. However, in the future it is possible that the role of education equality will be a major focus for the fulfillment of compulsory education launched by the government.

\section{Conclusions}

Education is the handle of four humans to be able to earn a better livelihood. Various educational paths are provided to the fulfillment of the right to education. To be able to carry out good education outside formal education, the need for sanctioning body is consistently and continuously. Because though education is increasing social welfare, standard weighs jobs requiring minimal education requirements. So far the role of institutions that move from social activities, one of which PKBM Kasih Bundo has brought good results.

\section{References}

Arikunto, S. (2002). Metode penelitian. Jakarta: Rineka Cipta, 89-71.

Best, J. (2003). Killing the messenger: The social problems of sociology. Social Problems, 50(1), 1-13.

Gee, K. A. (2015). Achieving gender equality in learning outcomes: Evidence from a non-formal education program in Bangladesh. International Journal of Educational Development, 40, 207-216.

Kaufmann, K. (2015). Non-Formal Education in International Comparison: Patterns of Participation and Investment in Selected European Countries. International Journal for Research in Vocational Education and Training, 2(4), 239-267.

Kedrayate, A. (2012). Non-formal education: Is it relevant or obsolete. International Journal of Business, Humanities and Technology, 2(4), 1-5.

Kuenzi, M. (2005). Non-formal education and community development in Senegal. Community development journal, 41(2), 210-222. 
Mfum-Mensah, O. (2003). Fostering educational participation in pastoral communities through nonformal education: the Ghanaian perspective. International Journal of Educational Development, 23(6), 661-677.

Morton, M. H., \& Montgomery, P. (2012). Empowerment-based non-formal education for Arab youth: A pilot randomized trial. Children and Youth Services Review, 34(2), 417-425.

Mumford, M. D., Zaccaro, S. J., Harding, F. D., Jacobs, T. O., \& Fleishman, E. A. (2000). Leadership skills for a changing world: Solving complex social problems. The Leadership Quarterly, 11(1), 11-35

Nieto, S., \& Ramos, R. (2013). Non-formal Education, overeducation and Wages. Revista de Economía aplicada, 21(61).

Olcott, D. (2013). New pathways to learning: Leveraging the use of oers to support non-formal education. International Journal of Educational Technology in Higher Education, 10(1), 327-344.

Nomor, U. U. R. I. (20). Tahun 2003.(2003). Sistem Pendidikan Nasional

Preece, J. (2013). Africa and international policy making for lifelong learning: textual revelations. International Journal of Educational Development, 33(1), 98-105.

Purwanto, E. A. (2007). Metode penelitian kuantitatif untuk administrasi publik dan masalah-masalah sosial. Gava Media.

Romi, S., \& Schmida, M. (2009). Non- formal education: a major educational force in the postmodern era. Cambridge Journal of Education, 39(2), 257-273.

Souto-Otero, M., Ulicna, D., Schaepkens, L., \& Bognar, V. (2013). Study on the impact of Non-Formal Education in youth organisations on young people's employability. In Brussels: European Youth Forum.

Stromquist, N. P. (2015). Women's Empowerment and Education: linking knowledge to transformative action. European Journal of Education, 50(3), 307-324.

Sugiyono. 2014. Metode Peneltitian Kuantitatif, Kualitatif dab R\&D. Bandung: Alfabeta

Thompson, E. J. (2001). Successful Experiences in Non-Formal Education and Alternative Approaches to Basic Education in Africa.

Wilkinson, R., \& Pickett, K. (2010). The spirit level. Why equality is better for.

Yasunaga, M. (2014). Non-formal education as a means to meet learning needs of out-of-school children and adolescents. Background Paper prepared for Fixing the Broken Promise of Education for All: Findings from the Global Initiative on Out-of-School Children. Montreal: UNESCO Institute for Statistics, 120. 